\title{
Indirect Evidence on Sex Reversal of Sinonovacula constricta (Bivalvia: Euheterodonta) and Gomphina veneriformis (Bivalvia: Veneridae)
}

\author{
Yun Kyung Shin ${ }^{1},{ }^{\dagger}$ Jung Jun Park ${ }^{1}, J_{i}$ Sung Choi ${ }^{2}$ and Jung Sick Lee ${ }^{2}$ \\ ${ }^{1}$ Aquaculture Management Division, Aquaculture Research Institute, NFRDI, Busan 619-902, Korea \\ ${ }^{2}$ Department of Aqualife Medicine, Chonnam National University, Yeosu 550-749 Korea
}

\begin{abstract}
This study attempts to propose the possibility of the sex reversal in Sinonovacula constricta and Gomphina veneriformis by confirming the changes in the sex ratio with the shell length in the same population level. For analysis of sex ratio, 100 individuals of S. constricta (SL 26.5-95.0 mm) and 2385 individuals of G. veneriformis (SL 15.1-60.1 mm) were used. Sex was analyzed histologically. Both species displayed the tendency of increase in the female proportion with increase in shell length. In this study, changes in the sex ratio in accordance with the growth of S. constricta and G. veneriformis are determined to be indirect evidence that signifies their sex reversal.
\end{abstract}

Key words : S. constricta, G. veneriformis, Sex ratio, Sex reversal

\section{INTRODUCTION}

Sex of bivalves is classified into gonochorism and hermaphroditism, and hermaphroditism is further divided into synchronous (simultaneous or functional) and asynchronous (sequential) hermaphroditism. The asynchronous hermaphroditism signifies sex reversal in accordance with seasons, resultantly (Heller, 1993; Gosling, 2004).

Indirect evidence of sex reversal in bivalves is a change in the sex ratio of a population with shell size (Orton, 1933; Galtsoff, 1964; Guo et al., 1998; Eversole, 2001; Gosling, 2004; Lee et al., 2012). Sex reversal of bivalves has been reported in the Ostreidae (Orton, 1933; Galtsoff, 1964; Thompson et al., 1996; Guo et al., 1998; Gosling, 2004), Pectinidae (Osanai, 1975; Ventilla, 1982) and Veneridae (Eversole, 2001; Lee et al., 2013).
This study attempted to present indirect evidence on the sex reversal of Sinonovacula constricta and Gomphina veneriformis by examining the changes in sex ratio with shell length and also to suggest basic information to definitively investigate their sex.

\section{MATERIALS AND METHODS}

\section{Materials}

Sinonovacula constricta used for sex ratio analysis was collected from the Namyang Bay on the western coast of Korea from April 1997 to March 1998. Total number of $S$. constricta used for sex ratio analysis was 100 animals (shell length 26.5-95.0 mm) (Table 1). Gomphina veneriformis used for sex ratio analysis was collected from Joomoonjin on the eastern coast of Korea from October 2005 to August

\footnotetext{
Manuscript received 19 March 2014, Received in revised form 27 March 2014, Accepted 3 April 2014

${ }^{\dagger}$ Corresponding Author : Jung Jun Park, Aquaculture Management Division, Aquaculture Research Institute, NFRDI, Busan 619-902, Korea. Tel. : +82 51-72-2422, E-mail : pjj515@korea.kr

This is an Open Access article distributed under the terms of the Creative Commons Attribution Non-Commercial License (http:// creativecommons.org/licenses/by-nc/3.0) which permits unrestricted non-commercial use, distribution, and reproduction in any medium, provided the original work is properly cited.
} 
2007. Total number of the clam used for sex ratio analysis was 2385 (shell length 15.1-70.0 mm) (Table 2).

\section{Sex ratio}

The sex ratios were computed with the following equation to illustrate the percentage (\%) of the females.

Female $(\%)=[$ Female $/$ Female + Male $] \times 100$

\section{Histological analysis}

Histological techniques were used to confirm the sex and gonadal development of each specimen. Specimen preparation for light microscopy was performed according to the methodology of Drury \& Wallington (1980). The clams were dissected, and their visceral mass, which included the gonad, was fixed in aqueous Bouin's solution for $18 \mathrm{~h}$ and rinsed in running water for $24 \mathrm{~h}$ and then dehydrated through a graded ethanol series (70-100\%). The tissues were embedded in paraplast (McCormick, USA). Embedded tissues were sectioned at 4-6 um thickness using a microtome (RM2235, Leica, Germany). Samples were stained with Mayer's hematoxylin- $0.5 \%$ eosin (H-E).

\section{Statistical analysis}

Statistical analyses were performed using SPSS 18.0 (SPSS Inc., Microsoft Co. WA). Sex ratio was assessed by Chi-square $\left(\chi^{2}\right)$ test. In all cases significance was established at $P<0.05$.

\section{RESULTS}

\section{Sinonovacula constricta}

The female proportion $(\mathrm{F} / \mathrm{F}+\mathrm{M})$ for the entire population of $S$. constricta was $41.0 \%$. However, sex ratio was found to differ when the clams were divided into groups according to shell length in $10.0 \mathrm{~mm}$ intervals. Sex ratio displayed the results of the tendency of increase in the proportion of female as increased in shell length (Table 1).

\section{Gomphina veneriformis}

The female proportion $(\mathrm{F} / \mathrm{F}+\mathrm{M})$ for the entire population of G. veneriformis was $50.0 \%$. However, sex ratio was found to differ when the clams were divided into groups according to shell length in $5.0 \mathrm{~mm}$ intervals. Although there was tendency of increase in the proportion of female as shell length increased (Table 2).

\section{DISCUSSION}

There was a case in which sexual dimorphism in bivalves was reported in Dysnomiacap saeformis and D. brevidens (Mackie, 1984). However, since it is difficult to distinguish sex macroscopically, histological analysis of gonads remains the only conclusive method. However, this method cannot be carried out without killing the organism (Gosling, 2004).

Although the sex of the majority of bivalves cannot be identified externally, the ratio of females to males is the same and they are generally gonochoristic (Gosling, 2004). Hermaphroditism (synchronous or asynchronous) in bivalves was recorded in 13 families among 117 analyzed families (Heller, 1993).

Synchronous hermaphroditism is the simultaneous release of eggs and sperm by one organism during the same season. Asynchronous hermaphrodities function first as one sex, then as another. Asynchronous hermaphrodities can be protandrous, protogynous or can alternate sexuality (Heller, 1993). Synchronous hermaphroditism in bivalves has been reported in Anodonta grandis (Van Der Schalie\& Locke, 1941) and Elliptio (Heard, 1979) of Unionidae; Argopecten irradians (Sastry, 1979), Chlamyso percularis (Sastry, 1979) and Pecten latiauritus (Mackie, 1984) of Pectinidae; Fulviamutica of Cardiidae (Chang \& Lee, 1982); Corbicula fluminea of Corbiculidae (Britton \& Morton, 1982); and Gemma spp. of Veneridae (Mackie, 1984). Asynchronous hermaphroditism in bivalves has been reported in Crassostrear ivularis, C. madrasensis, Saccostrea glomerata and S. cucculata (Asif, 1979), Ostreaedulis (Sastry, 1979; 
Table 1. Sex ratio with shell size of Sinonovacula constricta

\begin{tabular}{|c|c|c|c|c|c|c|c|}
\hline \multirow{2}{*}{ Shell length(mm) } & \multicolumn{3}{|c|}{ Number } & \multicolumn{2}{|c|}{ Sex ratio } & \multirow{2}{*}{$\chi^{2}$} & \multirow{2}{*}{$P$-value } \\
\hline & Total & Female & Male & $\mathrm{F} / \mathrm{F}+\mathrm{M}$ & $\mathrm{F}: \mathrm{M}$ & & \\
\hline$\leq 30.0$ & 4 & 1 & 3 & 0.25 & $1: 3.00$ & 1.000 & 0.317 \\
\hline $30.1-40.0$ & 17 & 5 & 12 & 0.29 & $1: 2.40$ & 2.882 & 0.090 \\
\hline $40.1-50.0$ & 10 & 3 & 7 & 0.30 & $1: 2.33$ & 1.600 & 0.206 \\
\hline $50.1-60.0$ & 23 & 9 & 14 & 0.39 & $1: 1.56$ & 1.087 & 0.297 \\
\hline $60.1-70.0$ & 26 & 12 & 14 & 0.46 & $1: 1.17$ & 0.154 & 0.695 \\
\hline $70.1-80.0$ & 14 & 8 & 6 & 0.57 & $1: 0.75$ & 0.286 & 0.593 \\
\hline $80.1 \leq$ & 6 & 3 & 3 & 0.50 & $1: 1.00$ & 0.000 & 1.000 \\
\hline Total & 100 & 41 & 59 & 0.41 & $1: 1.44$ & 3.240 & 0.072 \\
\hline
\end{tabular}

Table 2. Sex ratio with shell size of Gomphina veneriformis

\begin{tabular}{|c|c|c|c|c|c|c|c|}
\hline \multirow{2}{*}{$\begin{array}{l}\text { Shell length } \\
\quad(\mathrm{mm})\end{array}$} & \multicolumn{3}{|c|}{ Number } & \multicolumn{2}{|c|}{ Sex ratio } & \multirow{2}{*}{$\chi^{2}$} & \multirow{2}{*}{$P$-value } \\
\hline & Total & Female & Male & $\mathrm{F} / \mathrm{F}+\mathrm{M}$ & $\mathrm{F}: \mathrm{M}$ & & \\
\hline$\leq 20.0$ & 10 & 4 & 6 & 0.40 & $1: 1.50$ & 0.400 & 0.527 \\
\hline $20.1-25.0$ & 30 & 14 & 16 & 0.47 & $1: 1.14$ & 0.133 & 0.715 \\
\hline $25.1-30.0$ & 1025 & 501 & 524 & 0.49 & $1: 1.05$ & 0.516 & 0.473 \\
\hline $30.1-35.0$ & 650 & 341 & 309 & 0.52 & $1: 0.91$ & 1.575 & 0.209 \\
\hline $35.1-40.0$ & 437 & 218 & 219 & 0.50 & $1: 1.00$ & 0.002 & 0.962 \\
\hline $40.1-45.0$ & 158 & 79 & 79 & 0.50 & $1: 1.00$ & 0.000 & 1.000 \\
\hline $45.1-50.0$ & 53 & 28 & 25 & 0.53 & $1: 0.89$ & 0.170 & 0.680 \\
\hline $50.1-55.0$ & 12 & 4 & 8 & 0.33 & $1: 2.00$ & 1.333 & 0.248 \\
\hline $55.1 \leq$ & 10 & 6 & 4 & 0.60 & $1: 0.67$ & 0.400 & 0.527 \\
\hline Total & 2385 & 1195 & 1190 & 0.50 & $1: 1.00$ & 0.010 & 0.918 \\
\hline
\end{tabular}

Gosling, 2004), C. virginica (Mackie, 1984; Gosling, 2004) of Ostreidae and Mercenaria mercenaria (Sastry, 1979; Gosling, 2004) and Ruditapes philippinarum (Lee et al., 2013) of Veneridae.

Although sex reversal has been reported for other bivalves, such as Patinopecten yessoensis (Osanai, 1975; Ventilla, 1982), sex reversal studies have traditionally been conducted on oysters. Historically, the literature points to the higher proportion of males at the early stage, with increasing proportion of females arising through sex reversal at older stages of oysters (Orton, 1933; Coe, 1934; Galtsoff, 1964; Thompson et al., 1996; Guo et al., 1998).

European oyster, O. edulis exhibits between 10-16\% male to female sex reversal in the first year, and approximately $50 \%$ male to female sex reversal in the second year, respectively (Orton, 1933). They mature as males initially and undergo sex reversal into females after the first discharge of sperm, while sex reversal is repeated throughout 

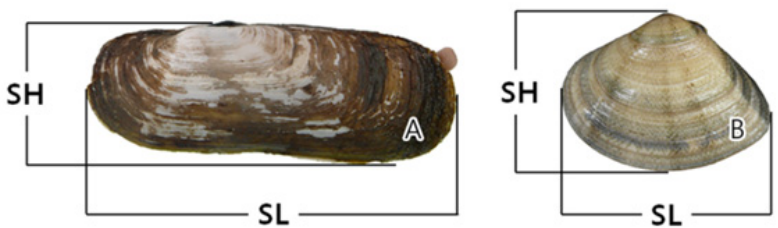

Fig. 1. External morphology and morphometric characteristics Sinonovacula constricta (A) and Gomphina veneriformis (B). SH, shell height; SL, shell length.

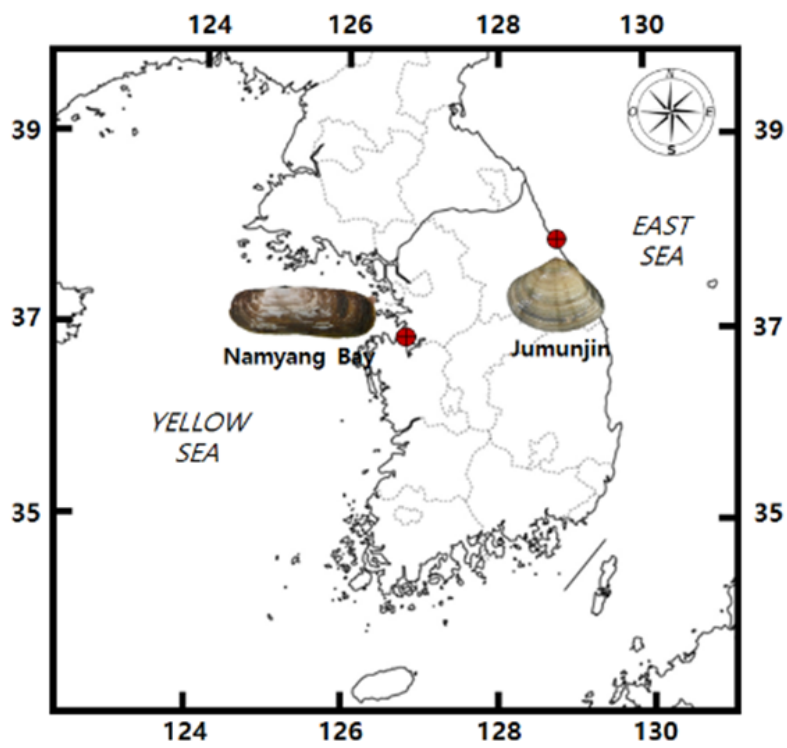

Fig. 2. Sampling area of Sinonovacula constricta and Gonphina veneriformis.

their life cycle (Walne, 1974). Quahog clam, M. mercenaria, become sexually mature at less than one year old, developing first as males but changing to an equal sex ratio in the second year (Menzel, 1989).

Sex of $S$. comstricta has been reported to be gonochoristic (Han et al., 2005) also reported the sex of $G$. veneriformis to be gonochoristic (Park et al., 2003). These conclusions on the sex of $S$. comstricta (Han et al., 2005) and $G$. veneriformis (Park et al., 2003) may have been reached because of the limited investigation undertaken by these authors some stage of the life cycle of $S$. constricta and $G$. veneriformis rather than continuous tracking of the reproductive life-history over a long period.
However, in this study, sex reversal is forecasted for $S$. constricta and $G$. veneriformis based on the results of analysis of changes in the sex ratio with shell sizes. Therefore, the possibility that the sex of these species is asynchronous hermaphroditism is very high.

Another indication of indirect evidence is the fact that large number of bivalves have an inactive stage during the reproductive cycle and classification of morphological sex is impossible as the gonad tissue is completely degenerated during this period (inactive stage) (García-Domínguez et al., 1994; Behzadi et al., 1997; Villalejo-Fuerte \& GarcíaDomínguez, 1998; Park et al., 2003). In the case of these bivalves, there is possibility that they may develop as different sex when the next reproductive cycle begins.

C. virginica and $R$. philippinarum are protandric species with an increase in the proportion of females through sex reversal as it ages. Sex reversal normally occurs when the gonad is undifferentiated between spawning seasons (Thompson et al., 1996; Lee et al., 2013). Although the sex of the scallop Patinopecten yessoensis, is male during the young stage of less than one year, sex is thereafter reversed to female. Histological analysis showed that their sex is not reversed during the inactive stage of their reproductive cycle, but is rather reversed through continuous stages during the reproductive cycle (Osanai, 1975).

From the results of Park et al. (2003), which histologically analyzed the gonad through all the stages of the reproductive cycle of $G$. veneriformis, no observation could be made of the histological characteristics of the gonad that illustrated the process of sex reversal at any stage of the reproductive cycle. Therefore, it is determined that the sex reversal of $G$. veneriformis occurs during the inactive stage following the spawning season.

Two factors, namely genetic and environmental, are involved in the changes in sex ratio and sex determination of bivalves. In the case of Pomacea canaliculata, $C$. gigas and Mytilus sp., an oligogenic sex determination method 
was used, which is a mechanism that results in highly diversified sex ratio and sex determination by small number of genes (Guo et al., 1998; Yusa, 2007). Factors such as temperature, food availability and day length are involved in environmental sex determination of bivalves (Yusa, 2007). Changes in sex ratio due to exposure to pollutants, such as EDCs and heavy metals during the inactive season, have also been reported in Mya arenaria (Gagné et al., 2005), G. veneriformis (Lee \& Park, 2007; Ju et al., 2009) and Scapharca broughtonii (Lee et al., 2009).

As the result of this study, although the sex reversal of $S$. constricta and G. veneriformisis predicted, additional researches are necessary for presentation of direct evidences for and environmental factors of sex reversal in these species.

\section{ACKNOWLEDGEMENTS}

This work was undertaken by a grant from the National Fisheries Research and Development Institute (NFRDI), contribution number RP-2014-AQ-029.

\section{REFERENCES}

Asif M (1979) Hermaphroditism and sex reversal in the four common oviparous species of oysters from the coast of Karachi. Hydrobiologia 66:49-55.

Behzadi S, Parivar K, Roustaian P (1997) Gonadal cycle of pearl oyster, Pinctada fucata (Gould) in northeast Persian Gulf, Iran. J Shellfish Res 16:129-135.

Britton AC, Morton B (1982) A dissection guide, field and laboratory manual for the introduced bivalve Corbicula fluminea. Malacol Rev Suppl 3:1-82.

Chang YJ, Lee TY (1982) Gametogenesis and reproductive cycle of the cockle, Fulvia mutica (Reeve). Bull Kor Fish Soc 15:241-253.

Coe WR (1934) Alternation of sexuality in oysters. Amer Nat 68:236-251.
Drury RAB, Wallington EA (1980) Carleton's Histological Technique. Oxford University Press, Oxford, pp 520.

Eversole AG (2001) Reproduction in Mercenaria mercenaria. In: Kraeuter JN, Castagna M (eds) Biology of the Hard Clam, Elsevier, New York, pp 221-260.

Gagné F, Blaise C, Pellerin J, Pelletier E, Strand J (2005) Health status of Mya arenaria bivalves collected from contaminated sites in Canada (Saguenay Fjord) and Denmark (Odense Fjord) during their reproductive period. Ecotoxicol Environ Saf 64:348-361.

Galtsoff PS (1964) The American oyster Crassostrea virginica Gmelin. Fish Bull 64:1-480.

García-Domínguez F, García-Gasca SA, Castro-Ortiz JL (1994) Spawning cycle of the red clam, Megapitaria aurantiaca (Sowerby, 1831) (Veneridae) at Isla Espiritu Santo, Baja California Sur, Mexico. J Shellfish Res 13:417-423.

Gosling E (2004) Bivalve Molluscs: Biology, Ecology and Culture. Blackwell Science, Oxford, p 443.

Guo X, Hedgecock D, Hershberger WK, Cooper K, Allen SK Jr (1998) Genetic determinants of protandric sex in the Pacific oyster, Crassostrea gigas Thunberg. Evolution 52:394-402.

Han JS, Kim JB, Lee CH, Chung EY (2005) Changes in biochemical components of several tissues in Sinonovacula constricta, in relation to gonad developmental phases. Korean J Malaco 21:121-132.

Heard WH (1979) Hermaphroditism in Elliptio (Pelecypoda: Unionidae). Malacol Rev 12:21-28.

Heller J (1993) Hermaphroditism in molluscs. Biol J Linne Soc 48:19-42.

Ju SM, Park JJ, Lee JS (2009) Induction of intersex and masculinization of the equilateral venus, Gomphina veneriformis (Bivalvia: Veneridae) by zinc. Anim Cells and Syst 13:339-344.

Lee JS, Cho HS, Jin YG, Park JJ, Shin YK (2009) Reproductive disrupting effect of organotin compound 
in the ark shell, Scapharca broughtonii (Bivalvia: Arcidae). Anim Cells and Syst 13:223-227.

Lee JS, Ku K, Kim H, Park JS, Park JJ, Shin YK, Jeon MA (2012) Indirect evidence on sex reversal with sex ratio of Tegillarca granosa (Bivalvia: Arcidae) and Ruditapes philippinarum (Bivalvia: Veneridae). Dev Reprod 16:177-183.

Lee JS, Park JJ (2007) Risk assessment of nonylphenol using the sex ratio, sexual maturation, intersex and lipofuscin accumulation of the equilateral venus, Gomphina veneriformis (Bivalvia: Veneridae). J Kor Fish Soc 40:16-23.

Lee JS, Park JS, Shin YK, Lee YG, Park JJ (2013) Sequential hermaphroditism in Manila clam Ruditapes philippinarum (Bivalvia: Veneridae). Invertebr Reprod Dev 57:185-188.

Mackie GL (1984) Bivalves. In: Tompa AS, Verndonk NH, Biggelaar JAM (eds) The Mollusca, Reproduction, vol. 7. Academic Press, New York, pp 351-418.

Menzel W (1989) The biology, fishery and culture of Quahog Clam, Mercenaria. In: Manzi JJ, Castagna M (eds) Clam Culture in North America. Elsevier Science Publishers, Amsterdam, pp 201-242.

Orton JH (1933) Observations and experiments on sexchange in the European oyster (O. edulis). Part III. On the fate of unspawned ova. Part IV. On the change from male to female. J Mar BiolAss`n 6:1-54.

Osanai K (1975) Seasonal gonad development and sex alteration in the scallop Patinopecten yessoensis. Bull
Mar BiolStn Asamushi 15:81-88.

Park JJ, Lee JY, Lee JS, Chang YJ (2003) Gonadal development and gametogenic cycle of the equilateral venus, Gomphina veneriformis (Bivalvia: Veneridae). J Kor Fish Soc 36:352-357.

Sastry AN (1979) Pelecypoda (excluding Ostreidae). In: Giese AG, Pearse PJ (eds) Reproduction of Marine Invertebrates, vol. 5. Academic Press, New York, pp 113-292.

Thompson RJ, Newell RIE, Kennedy VS, Mann R (1996) Reproductive process and early development. In: Kennedy VS, Newell RIE, Eble AF (eds) The Eastern Oyster Crassostrea virginica. Maryland Sea Grant, College Park, Maryland, pp 335-370.

van der Schalie H, Locke F (1941) Hermaphroditism in Anodonta grandis a freshwater mussel. Science 432:1-7.

Ventilla RF (1982) The scallop industry in Japan. Adv Mar Biol 20:310-382.

Villalejo-Fuerte M, García-Domínguez F (1998) Reproductive cycle of Spondylus leucacanthus (Broderip, 1833) (Bivalvia: Spondylidae) at Isla Danzante, Gulf California. J Shellfish Res 17:1037-1042.

Walne PR (1974) Culture of Bivalve Molluscs: 50 Years` Experience at Conwy. Fishing News (Books) Ltd, Surrey, pp 173.

Yusa Y (2007) Causes of variation in sex ratio and modes of sex determination in the Mollusca - an overview. Amer Malac Bull 23:89-98. 